\title{
Effect of Microbial Consortium and Organic Manure on Growth and Nutrients Uptake in Pearl Millet (Pennisetum glaucum L.)
}

\author{
D. Lasya Mohana Rekha*, R. Lakshmipathy and A. Vijaya Gopal \\ Department of Agricultural Microbiology, APGC, Lam, Guntur-522034, \\ Andhra Pradesh, India \\ *Corresponding author
}

\begin{abstract}
A B S T R A C T
Field experiment was conducted to study the effect of microbial consortium consisting of

\begin{tabular}{|c|}
\hline Keywords \\
\hline $\begin{array}{l}\text { Pearl millet, Azospirillum, } \\
\text { Azotobacter, PSB, KRB, } \\
\text { AM-fungi }\end{array}$ \\
\hline Article Info \\
\hline $\begin{array}{l}\text { Accepted: } \\
\text { 20 May } 2018 \\
\text { Available Online: } \\
\text { 10 June } 2018\end{array}$ \\
\hline
\end{tabular}
biofertilizers viz. nitrogen fixers, $\mathrm{P}$ solubilizer, $\mathrm{K}$ releasing bacteria and nutrients mobilizers were used. A pot culture experiment was conducted during the year 2016-17 at Agriculture Research Station, Amaravathi. There were two microbial consortia (MC1 and MC2) consisting of nitrogen fixers Azospirillum and Azotobacter were applied alone and with recommended dose of FYM to the soil treated with different doses of chemical fertilizers. Plant growth characteristics viz; plant height, number of leaves per plant, shoot and root dry biomass and nutrient $(\mathrm{N}, \mathrm{P}, \mathrm{K})$ uptake were found to be maximum in the treatment $\mathrm{T}_{11}(\mathrm{MC} 1+75 \% \mathrm{RDF}+\mathrm{FYM})$. Inoculated and un-inoculated plants were colonized by AM fungi. Inoculated plants were significantly colonized compared to application of 100 percent RDF alone. Results also showed that bio-fertilizer tended to reduce the application rates of chemical fertilizers. Microbial consortia (Azospirillum) MC1 along with recommended dose of FYM and 75 per cent recommended dose of chemical fertilizers could be recommended for pearl millet production in the study area.
\end{abstract}

\section{Introduction}

Pearl millet (Pennisetum americanum L.) is a tall, warm season and an annual grass belongs to family Poaceae. It is locally known as Bajra, a very important dual-purpose summer crop grown for both fodder and grain.

It can grow up to a height of 6 to 10 feet as conditions of $20^{\circ}$ to $30^{\circ} \mathrm{C}$ temperatures and optimum moisture prevails (Faridullah et al., 2010 India is the largest producer of pearl millet in terms of production $(10.05 \mathrm{~m} \mathrm{t})$ with an average productivity of $1156 \mathrm{~kg} / \mathrm{ha}$
(Bhardwaj et al., 2014). Most of the pearl millet in India is grown during rainy season (kharif-June to September) but is also cultivated during summer (February-May) in Gujarat, Rajasthan and Uttar Pradesh and during post-rainy season (Rabi- November to February) in small scale in Maharashtra and Gujarat. (AICRP on pearl millet, 2015).

Biofertilizers keep the soil environment rich in all kinds of micro- and macro-nutrients via nitrogen fixation, phosphate and potassium solubilisation or mineralization, release of plant growth promoting substances, 
production of antibiotics and biodegradation of organic matter in the soil (Sivakumar et al., 2013) providing a better nutrient uptake and increased tolerance towards drought and moisture stress. The beneficial microorganisms used in place of chemical fertilizers, are not only able to improve the plant growth but also maintain the environmental health and productivity of the soil. The role of biofertilizers alone or in combination with organic or inorganic fertilizers has recently gained recognition in sustainable crop production (Abdullahi and Sheriff, 2013). Considering all these benefits of biofertilizers, this study was taken up in bajra to enhance the yield and to reduce the use of chemical fertilizers.

\section{Materials and Methods}

The pot experiment was carried out to study the effect of inoculation of efficient biofertilizers consortia (Azospirillum+ $\mathrm{P}$ solubiliser $+\mathrm{K}$ solubiliser $+\mathrm{VAM})$ and $($ Azotobacter $+\mathrm{P}$ solubiliser $+\mathrm{K}$ solubiliser + VAM) on growth and yield of pearl millet at Agricultural Research station, Amaravathi during the year 2016-2017. The biofertilizers used in the two microbial consortia were collected from Agricultural Research station, Amaravathi.

These cultures were mixed with recommended dose of FYM and then applied to soil $(6 \mathrm{~kg}$ pot-1) filled in the pots prior to application of recommended dose of chemical fertilizers and then sowing was taken up. The experiment was laid out in completely randomized design with thirteen treatments and three replications.

\section{Plant height}

Plant height was measured at regular intervals in each treatment and expressed in $\mathrm{cm}$. The mean value of the plants from 3 replications was recorded.

\section{Number of leaves}

Total number of leaves per plant in each treatment were counted at 30, 50, 75 (DAS) and at harvest time in each treatment. The mean value of the leaves from 3 replications was recorded.

\section{Root length}

Root length was recorded at harvest by removing the soil from the pot carefully by splash of water and measured the root length from tip of longest root to the stem collar region.

\section{Root dry weight}

Root weight was recorded after drying of root samples in hot air oven at $60^{\circ} \mathrm{C}$.

The mean root dry weight value of 3 samples was recorded and expressed in grams.

\section{Shoot dry weight}

The straw from pots after harvesting was dried under direct expose to sun, weighed and converted into $\mathrm{kg} / \mathrm{ha}$. Percent root colonization was determined by wet sieving and decanting method (Giovannetti and Mosse (1980).

\section{Nitrogen Content (\%)}

Nitrogen content (\%) in the plant samples was estimated by the micro Kjeldhal method (AOAC, 1965) using Kelplus N analyser.

\section{Phosphorus Content (\%)}

The di-acid digested plant samples were analyzed for phosphorus content by Vanado molybdate phosphoric acid method as described by Jackson (1967). The intensity of yellow color developed was measured by using spectrophotometer at $420 \mathrm{~nm}$. 


\section{Potassium Content (\%)}

Potassium content in the di-acid extract was determined by using flame photometer (AOAC, 1965).

\section{Uptake of Nutrients}

The uptakes of $\mathrm{N}, \mathrm{P}$ and $\mathrm{K}$ nutrients were calculated using the following formula and expressed in $\mathrm{kg} \mathrm{ha}^{-1}$.

Nutrient content (\%) X Dry matter production $\left(\mathrm{kg} \mathrm{ha}^{-1}\right)$ Uptake of nutrient $\left(\mathrm{kg} \mathrm{ha}^{-1}\right)=$

100

\section{Results and Discussion}

In this study, the growth and yield of pearl millet was enhanced with the inoculation of microbial consortia along with recommended dose of FYM and fertilizers compared to 100 per cent recommended dose of fertilizers (Table 1). Highest plant height was recoreded in the plants of the pots treated with $\mathrm{MC} 1+$ $75 \%$ RDF + FYM (129.66cm). Plant growth promoting rhizobacteria might enhance plant height and productivity by synthesizing phytohormones, increasing the local availability of nutrients, facilitating the uptake of plant nutrients by the plants (Hussain et al., 2013). Similar results reported by Rafi and Charyulu (2016). The number of leaves was highest in the plants of the pots treated with $\mathrm{MC} 1+\mathrm{FYM}$ and $\mathrm{MC} 1+75 \% \mathrm{RDF}+\mathrm{FYM}$ (16.00) followed by MC1 + 50\% RDF + FYM (15.33). The variation in number of leaves per plant between different treatments might be due to differences in availability and uptake of nutrients. Similar results were reported by Vasanthakumar (2003).

The root length was highest in the treatments with $\mathrm{MC1}+75 \%$ RDF + FYM $(28.833 \mathrm{~cm})$ followed by plants from the pots added with
$\mathrm{MC} 1+75 \% \mathrm{RDF}(28.5 \mathrm{~cm}), \mathrm{MC} 1+50 \%$ $\mathrm{RDF}+\mathrm{FYM}$ and $\mathrm{MC} 1+50 \% \mathrm{RDF}(28.333$ $\mathrm{cm})$. The increased root length in these treatments may be because of the availability of plenty of soluble form of phosphorous due to inoculation of PSB and AM fungi. Similar results reported by Gomaa and Kholas (1999) who reported that the root length in mungbean was increased with the combined application of organic manure, vermicompost, chemical and bio-fertilizers.

The highest straw yield was recorded in the plants of the pots inoculated with MC1 $+75 \%$ RDF + FYM (5977.00 kg ha $\left.{ }^{-1}\right)$. Similar results reported by Mane et al., (2000) who reported that dry weight of root enhanced with dual inoculation of Azospirillum with PSB. The dual inoculation of Azospirillum and PSB increased the dry root weight of ragi plants over other treatments (Rafi et al., 2012).

The highest NPK uptake was observed in the treatment $\mathrm{T}_{11}(\mathrm{MC} 1+75 \% \mathrm{RDF}+\mathrm{FYM}) 40.51$ $\mathrm{kg} \mathrm{ha}^{-1}, 25.02 \mathrm{~kg} \mathrm{ha}^{-1}, 60.24 \mathrm{~kg} \mathrm{ha}^{-1}$ and lowest $\mathrm{N}, \mathrm{P}$ recorded in the treatment $\mathrm{T}_{2}$ (MC2) 23.25 $\mathrm{kg} \mathrm{ha}^{-1}, 14.97 \mathrm{~kg} \mathrm{ha}^{-1}$ and lowest $\mathrm{K}$ recorded in the treatment $\mathrm{T}_{13}(100 \% \mathrm{RDF}) 46.56 \mathrm{~kg} \mathrm{ha}^{-}$ ${ }^{1}$. Bio-inoculants application enhances the root growth coupled with increased availability of nutrients in the rhizosphere by $\mathrm{N}_{2}$ fixation and, $\mathrm{P}$ and $\mathrm{K}$ solubilization which leads to increased nutrient uptake by the plants. Similar results were also reported in the earlier studies with respect to nutrient uptake in different crops due to microbial inoculants application. Abdullahi et al., (2013) reported the enhanced sesamum growth and nutrient uptake with the combination of biofertilizer and poultry manure application.

The highest percent root colonization was recorded in the treatment $\mathrm{T}_{11}(\mathrm{MC1}+$ 75\%RDF+FYM) $56.61 \%$ and lowest percent root colonization was recorded in the treatment $\mathrm{T}_{13}(100 \% \mathrm{RDF}) 23.33 \%$. 
Table.1 Influence of biofertilizers consortium on plant height and number of leaves and root length of pearl millet

\begin{tabular}{|c|c|c|c|c|}
\hline Treatments & $\begin{array}{c}\text { Plant } \\
\text { height } \\
\text { (cm) }\end{array}$ & $\begin{array}{l}\text { Number } \\
\text { of leaves }\end{array}$ & $\begin{array}{l}\text { Root length } \\
\text { plant }^{-1}(\mathrm{~cm})\end{array}$ & $\begin{array}{l}\text { Root dry weight } \\
\text { plant }^{-1} \text { (g) }\end{array}$ \\
\hline $\mathrm{T}_{1}-\mathrm{MC}_{1}$ & 100.50 & 13.67 & 22.50 & 1.57 \\
\hline $\mathrm{T}_{2}-\mathrm{MC} 2$ & 124.83 & 13.00 & 18.16 & 1.46 \\
\hline $\mathrm{T}_{3}-\mathrm{MC} 1+\mathrm{FYM}$ & 115.33 & 16.00 & 28.16 & 1.81 \\
\hline $\mathrm{T}_{4}-\mathrm{MC} 2+\mathrm{FYM}$ & 127.83 & 15.00 & 26.00 & 1.79 \\
\hline $\mathrm{T}_{5}-\mathrm{MC} 1+50 \% \mathrm{RDF}$ & 124.83 & 13.33 & 28.33 & 1.91 \\
\hline $\mathrm{T}_{6}-\mathrm{MC} 2+50 \% \mathrm{RDF}$ & 125.33 & 13.00 & 23.66 & 1.51 \\
\hline $\mathrm{T}_{7}-\mathrm{MC} 1+50 \% \mathrm{RDF}+\mathrm{FYM}$ & 126.00 & 15.33 & 28.33 & 1.97 \\
\hline $\mathrm{T}_{8}-\mathrm{MC}_{2}+50 \% \mathrm{RDF}+\mathrm{FYM}$ & 126.33 & 14.00 & 27.50 & 1.62 \\
\hline $\mathrm{T}_{9}-\mathrm{MC}_{1}+75 \% \mathrm{RDF}$ & 124.66 & 13.67 & 28.50 & 2.29 \\
\hline $\mathrm{T}_{10}-\mathrm{MC}_{2}+75 \% \mathrm{RDF}$ & 125.00 & 13.00 & 24.66 & 1.62 \\
\hline $\mathrm{T}_{11}-\mathrm{MC}_{1}+75 \% \mathrm{RDF}+\mathrm{FYM}$ & 129.66 & 16.00 & 28.83 & 3.29 \\
\hline $\mathrm{T}_{12}-\mathrm{MC}_{2}+75 \% \mathrm{RDF}+\mathrm{FYM}$ & 126.50 & 15.00 & 27.66 & 2.04 \\
\hline $\mathrm{T}_{13}-100 \% \mathrm{RDF}$ & 119.66 & 12.67 & 25.50 & 1.50 \\
\hline CD & 4.40 & 1.11 & 3.57 & 0.16 \\
\hline $\mathrm{SE}( \pm \mathrm{m})$ & 1.50 & 0.38 & 1.22 & 0.05 \\
\hline
\end{tabular}

Table.2 Influence of biofertilizers consortium on shoot dry weight, nutrient uptake and AM fungi root colonization (\%)

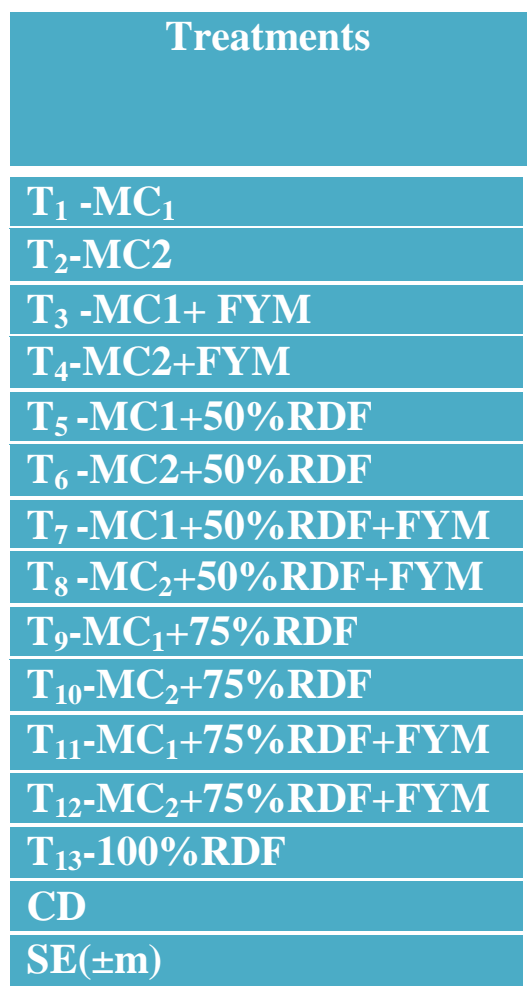

\begin{tabular}{|c|c|c|c|c|}
\hline $\begin{array}{c}\text { Shoot dry } \\
\text { weight }(\mathrm{Kg} \\
\left.\text { ha }^{-1}\right)\end{array}$ & $\begin{array}{c}\text { N- uptake } \\
\left(\mathrm{Kg} \mathrm{ha}^{-1}\right)\end{array}$ & $\begin{array}{l}\mathrm{P}-\text { uptake } \\
\left(\mathrm{Kg} \mathrm{ha}^{-1}\right)\end{array}$ & $\begin{array}{l}\mathrm{K}- \\
\text { uptake } \\
\left(\mathrm{Kg} \mathrm{ha}^{-1}\right)\end{array}$ & $\begin{array}{c}\text { Percent } \\
\text { Root } \\
\text { colonivation }\end{array}$ \\
\hline 5699.55 & 32.55 & 16.06 & 56.99 & 86.66 \\
\hline 5400.88 & 23.25 & 14.97 & 54.00 & 78.66 \\
\hline 5911.11 & 34.73 & 18.80 & 59.11 & 88.66 \\
\hline 5899.91 & 26.57 & 17.16 & 58.99 & 82.66 \\
\hline 5656.24 & 33.75 & 16.43 & 56.56 & 88.00 \\
\hline 5333.68 & 28.93 & 18.66 & 53.33 & 84.00 \\
\hline 5825.91 & 35.30 & 22.85 & 57.99 & 93.33 \\
\hline 5674.66 & 28.83 & 21.34 & 56.74 & 85.33 \\
\hline 5799.11 & 35.42 & 20.73 & 52.54 & 90.66 \\
\hline 5756.80 & 30.83 & 19.82 & 51.56 & 88.00 \\
\hline 5977.00 & 40.51 & 25.02 & 60.24 & 92.00 \\
\hline 5878.75 & 34.69 & 22.27 & 58.78 & 90.66 \\
\hline 5856.35 & 35.65 & 20.47 & 46.56 & 56.00 \\
\hline 209.35 & 2.59 & 1.30 & 2.67 & 4.92 \\
\hline 71.62 & 0.88 & 0.44 & 0.91 & 1.68 \\
\hline
\end{tabular}


Harinikumar and Bagyaraj (1989) also reported similar results, in their studies there was also a decrease in mycorrhizal colonization with increase in the rate of fertilization.

From the findings of this study, it can be concluded that treatment applied with MC1+75\% RDF+FYM could improve growth, nutrient uptake and percent root colonization compared to treatments applied with chemical fertilizers alone. Results also showed that biofertilizer Azospirillum showed higher growth and nutrient uptake than Azotobacter.

\section{References}

Abdullah, A.T., Hanafy, M.S., EL-Ghawwas, E.O and Ali, Z.H. 2012. Effect of compost and some biofertilizers on growth, yield, essential oil productivity and chemical composition of (Rosmarinus officinalis, L.) plants. Journal of Horticultural Science and Ornamental Plants. 4 (2): 201-214.

Abdullahi, R and Sheriff, H.H. 2013. Effect of arbuscular mycorrhizal fungi and chemical fertilizer on growth and shoot nutrients content of onion under field condition in Northern Sudan Savanna of Nigeria. Journal of Agriculture and Veterinary Science. 3 (5): 85-90.

AICRP 2015. Project Coordinator Review, Annual Workshop of All India Coordinated Millet Improvement Project, held at TNAU, Coimbatore on 23-25 April, 2015. www.acipmip.res.in.

Bhardwaj, V and Omanwar, P.K. 2014. Long term effect of continuous rotational cropping and fertilization on crop yields and soil properties II. Effects on EC, $\mathrm{pH}$, organic matter and available nutrient of soil. Journal of the Indian Society of the Soil Science. 42: 387-392.
Faridullah, A.A., Irshad, M., Khan, J., Khan, A.R., Sher, H and Khan, K. 2010. Comparative studies of different pearl millet varieties as affected by different yield components. Electronic Journal of Environmental, Agricultural and Food Chemistry. 9: 1524-1533.

Ghomaa, A.M and El- Kholas, M.A. 1993. Partial replacement of chemical fertilizers by biofertilizers in mungbean (Vigna radiata L.) production. Annals of Agricultural Sciences. 37(4): 24192434.

Harinikumar, K.M and Bagyaraj, D.J. 1989. Effect of cropping sequence, fertilizers, and farmyard manure on vesiculararbuscular mycorrhizal fungi in different crops over three consecutive seasons. Biology and Ferility of Soils. 7: 173-175.

Hussain, M.I., Asghar, H.N., Arshad, M and Shahbaz, M. 2013. Screening of multitraits rhizobacteria to improve maize growth under axenic conditions. The Journal of Animal and Plant Sciences. 23(2): 514-520.

Mane, S.S., Hadgaonkar, A.K., Suryawanshi, A.P and Salunke, S.D. 2000. Response of pearlmillet to inoculation of phosphorus solubilizing bacteria and Azospirillum. Journal of Indian Society of Soil Science. 48: 617-619.

Rafi, M.M.D., Varalakshmi, T and Charyulu, P.B.B.N. 2012. Influence of Azospirillum and PSB inoculation on growth and yield of Foxtail Millet. Journal of Microbiology Biotechnology and Research. 2(4): 558-565.

Rafi, M.MD and Charyulu, P.B.B.N. 2016. Synergistic effect of Azospirillum and PSB inoculation on growth and yield of foxtail millet. International Journal of Plant, Animal and Environmental Sciences. 6(1): 138-141. 
Sivakumar, T., Ravikumar, M and Prakash, M. 2013. "Thamizhmani R. Comparative effect on bacterial biofertilizers on growth and yield of green gram (Phaseolus radiate L.) and cow pea (Vigna siensis Edhl.)". International Journal of Current
Research and Academic Review. 1 (2): 20-28.

Vasanthakumar, S. K. 2003. Studies on beneficial endorhizosphere bacteria in solanaceous crop plants. M.Sc Thesis. University of Agricultural Sciences. Dharwad, Karnataka, India.

\section{How to cite this article:}

Lasya Mohana Rekha D., R. Lakshmipathy and Vijaya Gopal A. 2018. Effect of Microbial Consortium and Organic Manure on Growth and Nutrients Uptake in Pearl Millet (Pennisetum glaucum L.). Int.J.Curr.Microbiol.App.Sci. 7(06): 2256-2261.

doi: https://doi.org/10.20546/ijcmas.2018.706.269 